\title{
A simple copper-catalyzed two-step one-pot synthesis of indolo[1,2-a]quinazoline
}

\author{
Chunpu Li ${ }^{1,2}$, Lei Zhang ${ }^{2}$, Shuangjie Shu ${ }^{2}$ and Hong Liu ${ }^{*} 1,2$
}

\author{
Full Research Paper \\ Address: \\ ${ }^{1}$ Department of Medicinal Chemistry, China Pharmaceutical \\ University, 24 Tong Jia Xiang, Nanjing 210009, P. R. China and ${ }^{2}$ CAS \\ Key Laboratory of Receptor Research, Shanghai Institute of Materia \\ Medica, Chinese Academy of Sciences, 555 Zuchongzhi Road, \\ Shanghai 201203, P. R. China \\ Email: \\ Hong Liu* - hliu@mail.shcnc.ac.cn \\ * Corresponding author \\ Keywords: \\ copper; one pot; synthetic methods \\ Beilstein J. Org. Chem. 2014, 10, 2441-2447. \\ doi:10.3762/bjoc. 10.254 \\ Received: 03 June 2014 \\ Accepted: 08 August 2014 \\ Published: 21 October 2014 \\ Associate Editor: J. P. Wolfe \\ (c) 2014 Li et al; licensee Beilstein-Institut. \\ License and terms: see end of document.
}

\begin{abstract}
A convenient CuI/L-proline-catalyzed, two-step one-pot method has been developed for the preparation of indolo[1,2- $a$ ]quinazoline derivatives using a sequential Ullmann-type $\mathrm{C}-\mathrm{C}$ and $\mathrm{C}-\mathrm{N}$ coupling. This protocol provides an operationally simple and rapid strategy for preparing indolo[1,2-a]quinazoline derivatives and displays good functional group tolerance. All the starting materials are commercial available or can be easily prepared.
\end{abstract}

\section{Introduction}

Indole motifs are important in natural products and pharmaceutical compounds [1-5]. In particular, tetracyclic compounds containing the indole substructure represent an important structural motif in a variety of bioactive compounds, such as antitumor agents A [6] and antifungal agents B [7] (Figure 1). Therefore, it is necessary to develop efficient and convenient methods to prepare nitrogen-containing tetracyclic compounds incorporating the bioactive indole motif in organic chemistry and medicinal chemistry.

Over the past decades, copper catalysts have been proven highly powerful for various cross-coupling reactions, including Ullmann-type couplings of aryl halides with active methylene compounds such as ethyl acetoacetate, malononitrile, cyano-

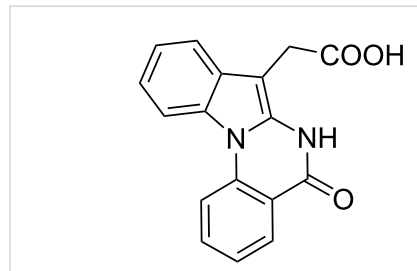

A

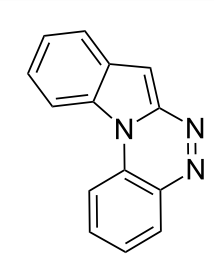

B
Figure 1: Representative examples of bioactive tetracyclic compounds containing the indole motif.

acetate and their equivalents [8-15]. Copper-catalyzed domino reactions have also been used in the synthesis of nitrogencontaining compounds [16-20]. Ma et al reported a convenient 
method for the synthesis of 2-(trifluoromethyl)indoles by introducing the trifluoroacetyl group to activate the $\mathrm{CuI} / \mathrm{L}$-prolinecatalyzed system [21]. Zhao [22] and Kobayashi [23] reported the synthesis of 2-amino- $1 H$-indole derivatives using the same kind of copper-catalyzed system. Meanwhile, the Ullmann condensation is a powerful method for $\mathrm{C}-\mathrm{N}$ coupling [24-26], especially the $N$-arylation of nitrogen-containing heterocycles such as indoles $[27,28]$. Indolo[1,2- $a]$ quinazoline is a kind of tetracyclic compounds containing the indole motif that has been constructed by intramolecular [3 +2$]$ cycloadditions of azidoketenimines and azido-carbodiimides (Scheme 1) [29]. The available starting materials for the synthesis of these compounds, however, are limited. Very recently, Perumal [30] reported an efficient method for the synthesis of indolo[1,2a] quinazoline through a $\mathrm{Cu}(\mathrm{I})$-catalyzed intramolecular domino cyclization. Based on the previous work for the coppercatalyzed synthesis of 2-amino- $1 H$-indole derivatives and copper-catalyzed $\mathrm{N}$-arylation, we herein report a simple and efficient one-pot method to synthesize indolo[1,2- $a$ ]quinazolines by a sequential Ullmann-type $\mathrm{C}-\mathrm{C}$ and $\mathrm{C}-\mathrm{N}$ coupling. Compared to the previous methods [29,30], the advantages of our method are as following: (1) All the starting materials are commercially available or easily prepared. (2) Functionalized indolo[1,2- $a]$ quinazoline derivatives can be synthesized, especially 7-cyano- or 7-sulfonyl-substituted indolo[1,2-a]quinazoline derivatives. (3) This protocol is performed as a two-step reaction in one pot.

\section{Results and Discussion}

Substituted $N$-(2-iodophenyl)acetamides 1 were synthesized from substituted 2 -iodoaniline by acetylation $[31,32]$. Substituted $o$-iodobenzaldehydes 3 were prepared from 2-iodobenzoic acid derivatives by reduction and PCC oxidation [33].
Initially, $N$-(2-iodophenyl)acetamide (1a), malononitrile (2a) and 2-iodobenzaldehyde (3a) were chosen as model substrates to optimize reaction conditions including the catalysts, bases and solvents under argon atmosphere. Based on the previous work [22], four copper catalysts were screened at $80{ }^{\circ} \mathrm{C}$ using L-proline as ligand, and $\mathrm{K}_{2} \mathrm{CO}_{3}$ as base in a mixed solvent of DMSO and $\mathrm{H}_{2} \mathrm{O}$ (volume ratio 1:1) (Table 1, entries 1-4). To our delight, the desired product 4 a was obtained in $36 \%$ yield using $\mathrm{CuI}$ as catalyst and $50 \%$ yield with $\mathrm{Cu}_{2} \mathrm{O}$ (Table 1 , entries 1 and 4). Considering that the formation of imine occurs in the second step, the presence of water in this system may hinder the reaction. To account for this, DMSO was chosen as solvent, and a higher yield (72\%) was obtained using $\mathrm{CuI}$ as the catalyst (Table 1, entry 6). The reactivity decreased slightly when $\mathrm{K}_{2} \mathrm{CO}_{3}$ was replaced with $\mathrm{Cs}_{2} \mathrm{CO}_{3}$ as the base (Table 1, entry 7). However, when a weaker base $\left(\mathrm{K}_{3} \mathrm{PO}_{4}\right)$ or an organic base (DBU) was used, the conversions of starting materials were lower (Table 1, entries 8 and 9). Some other solvents were investigated, iPrOH resulted in only trace of product, while no product was detected with 1,4-dioxane and DMF led to low yield (18\%) (Table 1, entries 10-12). Among the ligands screened, L-proline was more beneficial to the catalysis than L-hydroxyproline and picolinic acid (Table 1, entries 6, 13 and 14). When the reaction temperature was changed to $70{ }^{\circ} \mathrm{C}$ only traces of product were detected (Table 1, entry 15). Eventually, $\mathrm{CuI}$, the inexpensive ligand L-proline and two equivalents of $\mathrm{K}_{2} \mathrm{CO}_{3}$ as the base in DMSO were identified as the most efficient system (Table 1 , entry 6).

With the optimized conditions in hand, the scope of the coppercatalyzed reactions of substituted $N$-(2-iodophenyl)acetamides with malononitriles and substituted $o$-iodobenzaldehydes was investigated. As summarized in Table 2, the desired products

\section{Previous work:}

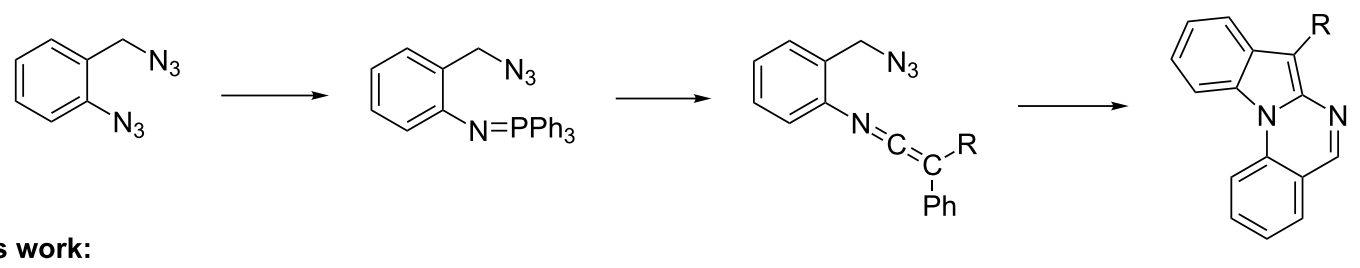

\section{This work:}

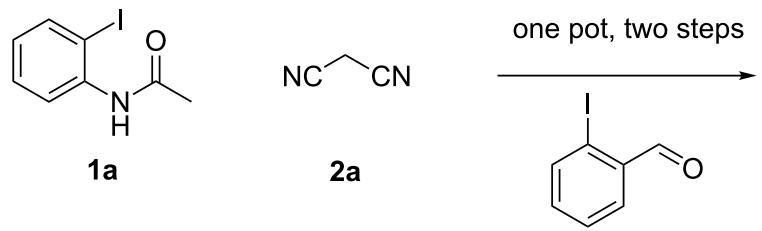

$3 a$

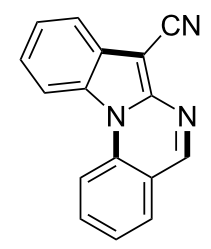

$4 a$ 
Table 1: Optimization of the reaction conditions. ${ }^{\text {a }}$

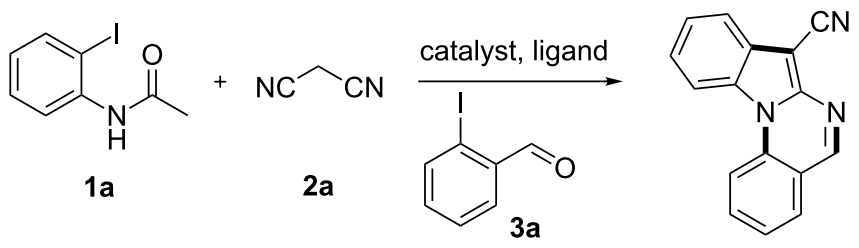

\begin{tabular}{|c|c|c|c|c|c|}
\hline Entry & Catalyst & Ligand $^{\mathrm{b}}$ & Base & Solvent & Yield $(\%)^{c}$ \\
\hline 1 & Cul & A & $\mathrm{K}_{2} \mathrm{CO}_{3}$ & $\mathrm{DMSO} / \mathrm{H}_{2} \mathrm{O}^{\mathrm{d}}$ & 36 \\
\hline 2 & $\mathrm{CuBr}$ & A & $\mathrm{K}_{2} \mathrm{CO}_{3}$ & $\mathrm{DMSO} / \mathrm{H}_{2} \mathrm{O}$ & 21 \\
\hline 3 & $\mathrm{Cu}(\mathrm{OAc})_{2}$ & $A$ & $\mathrm{~K}_{2} \mathrm{CO}_{3}$ & $\mathrm{DMSO} / \mathrm{H}_{2} \mathrm{O}$ & 16 \\
\hline 4 & $\mathrm{Cu}_{2} \mathrm{O}$ & A & $\mathrm{K}_{2} \mathrm{CO}_{3}$ & $\mathrm{DMSO} / \mathrm{H}_{2} \mathrm{O}$ & 50 \\
\hline 5 & $\mathrm{Cu}_{2} \mathrm{O}$ & A & $\mathrm{K}_{2} \mathrm{CO}_{3}$ & DMSO & 45 \\
\hline 6 & Cul & $A$ & $\mathrm{~K}_{2} \mathrm{CO}_{3}$ & DMSO & 72 \\
\hline 7 & Cul & A & $\mathrm{Cs}_{2} \mathrm{CO}_{3}$ & DMSO & 60 \\
\hline 8 & Cul & A & $\mathrm{K}_{3} \mathrm{PO}_{4}$ & DMSO & N.D. \\
\hline 9 & Cul & A & DBU & DMSO & N.D. \\
\hline 10 & Cul & A & $\mathrm{K}_{2} \mathrm{CO}_{3}$ & DMF & 18 \\
\hline 11 & Cul & A & $\mathrm{K}_{2} \mathrm{CO}_{3}$ & iPrOH & trace \\
\hline 12 & Cul & A & $\mathrm{K}_{2} \mathrm{CO}_{3}$ & 1,4-dioxane & N.R. \\
\hline 13 & Cul & B & $\mathrm{K}_{2} \mathrm{CO}_{3}$ & DMSO & 38 \\
\hline 14 & Cul & C & $\mathrm{K}_{2} \mathrm{CO}_{3}$ & DMSO & 31 \\
\hline $15^{\mathrm{e}}$ & Cul & A & $\mathrm{K}_{2} \mathrm{CO}_{3}$ & DMSO & trace \\
\hline
\end{tabular}

aReaction conditions: $1 \mathrm{a}(0.38 \mathrm{mmol}), \mathbf{2 a}(0.46 \mathrm{mmol}, 1.2$ equiv), catalyst $(0.038 \mathrm{mmol}, 0.1$ equiv), ligand $(0.076 \mathrm{mmol}, 0.2 \mathrm{equiv})$, base (0.76 mmol, 2 equiv) in $0.77 \mathrm{~mL}$ of solvent under argon atmosphere at $80{ }^{\circ} \mathrm{C}$ for $12 \mathrm{~h}$; then $3 \mathrm{a}$ in $0.77 \mathrm{~mL}$ of solvent, another $12 \mathrm{~h} .{ }^{\mathrm{b}} \mathrm{A}=\mathrm{L}-\mathrm{proline}, \mathrm{B}=\mathrm{L}$-hydroxyproline, $\mathrm{C}=$ picolinic acid. ${ }^{\mathrm{C}}$ Isolated yield. ${ }^{\mathrm{d}} \mathrm{DMSO} / \mathrm{H}_{2} \mathrm{O} 1: 1 .{ }^{\mathrm{e}}$ Reaction temperature: $70{ }^{\circ} \mathrm{C}$.

Table 2: Synthesis of indolo[1,2-a]quinazolines 4 . $^{\mathrm{a}}$

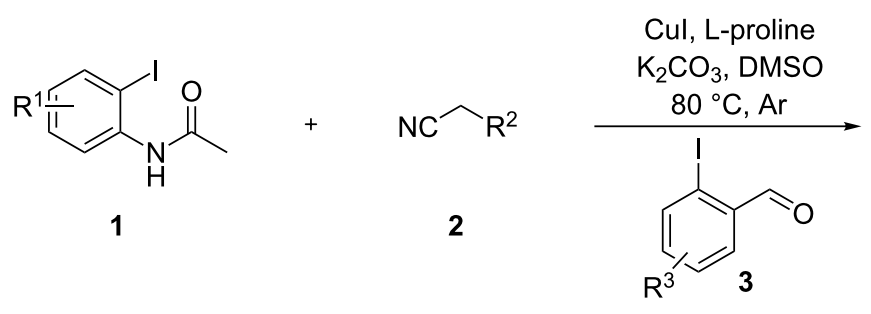

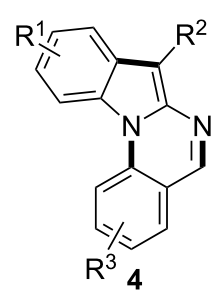

Entry


Table 2: Synthesis of indolo[1,2-a]quinazolines $4 .^{a}$ (continued)

3<smiles>COc1ccc(NC(C)=O)c(I)c1</smiles>

$1 c$<smiles>CC(=O)Nc1ccc(C(F)(F)F)cc1I</smiles>

$1 d$<smiles>COC(=O)c1ccc(NC(C)=O)c(I)c1</smiles>

$1 e$<smiles>CC(=O)Nc1ccc(F)cc1I</smiles><smiles>CC(=O)Nc1ccc(Cl)cc1I</smiles>

$1 \mathrm{~g}$<smiles>CC(=O)Nc1ccc(Br)cc1I</smiles>

1h<smiles>CC(=O)Nc1cc(F)ccc1I</smiles>

10<smiles>CC(=O)Nc1cc(Cl)ccc1I</smiles>

11

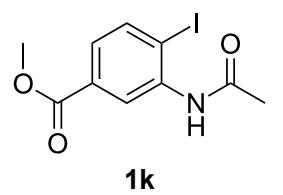

$2 a$

$3 a$<smiles>COc1ccc2c(c1)c(C#N)c1ncc3ccccc3n12</smiles>

45

$2 a$

$3 a$<smiles>N#Cc1c2cc(C(F)(F)F)ccc2n2c1ncc1ccccc12</smiles>

4d

$2 a$<smiles>COC(=O)c1ccc2c(c1)c(C#N)c1ncc3ccccc3n12</smiles>

$4 e$<smiles>N#Cc1c2cc(F)ccc2n2c1ncc1ccccc12</smiles>

$4 f$<smiles>N#Cc1c2ccccc2n2c1ncc1cc(Cl)ccc12</smiles>

$4 g$<smiles>N#Cc1c2cc(Br)ccc2n2c1ncc1ccccc12</smiles>

4h<smiles>N#Cc1c2ccc(F)cc2n2c1ncc1ccccc12</smiles>

$4 i$<smiles>N#Cc1c2ccc(Cl)cc2n2c1ncc1ccccc12</smiles>

4j<smiles>COC(=O)c1ccc2c(C#N)c3ncc4ccccc4n3c2c1</smiles>

49 51 49 56 51 54 
Table 2: Synthesis of indolo[1,2-a]quinazolines $4 .^{\mathrm{a}}$ (continued)

12
$1 \mathrm{a}$

$1 \mathbf{a}$

$1 \mathrm{a}$

$1 \mathbf{a}$

$1 a$

$1 a$<smiles>CS(=O)(=O)CC#N</smiles><smiles>N#CCS(=O)(=O)c1ccccc1</smiles>

2c

$2 a$<smiles>COc1cc(I)c(C=O)cc1OC</smiles>

3b

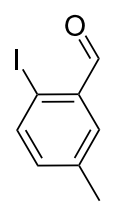

3c

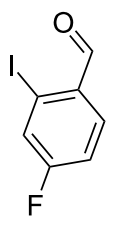

3d

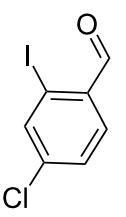

$3 e$<smiles>CS(=O)(=O)c1c2ccccc2n2c1ncc1ccccc12</smiles>

41<smiles>O=S(=O)(c1ccccc1)c1c2ccccc2n2c1ncc1ccccc12</smiles>

$4 m$<smiles>COc1cc2cnc3c(C#N)c4ccccc4n3c2cc1OC</smiles>

$4 n$<smiles>Cc1ccc2c(cnc3c(C#N)c4ccccc4n32)c1</smiles>

40<smiles>N#Cc1c2ccccc2n2c1ncc1ccc(F)cc12</smiles>

$4 p$<smiles>N#Cc1c2ccccc2n2c1ncc1ccc(Cl)cc12</smiles>

$4 q$

aReaction conditions: 1 (100 mg, 1 equiv), 2 (1.2 equiv), catalyst ( 0.1 equiv), ligand ( 0.2 equiv), base (2 equiv) in DMSO (0.5 M) under argon atmosphere at $80^{\circ} \mathrm{C}$ for $12 \mathrm{~h}$; then 3 in DMSO, another $12 \mathrm{~h}$. bIsolated yield.

$\mathbf{4 a}-\mathbf{4 q}$ were obtained in moderate to good yields (34-72\%) by treatment of various substituted $N$-(2-iodophenyl)acetamides $\mathbf{1 a}-\mathbf{1} \mathbf{k}$ with active methylene compounds $\mathbf{2 a}-\mathbf{2} \mathbf{c}$ and substituted $o$-iodobenzaldehydes 3a-3e. For $N$-(2-iodophenyl)acetamide substrates, an electron-donating $p$-methyl group afforded a good isolated yield of the desired product (Table 2, entry 2). However, substrate 1c with an electron-donating $p$-methoxy group was found to decrease the yield of the corresponding product (Table 2, entry 3). This result may be attributed to its low stability during the reaction. In comparison, electron-with- drawing $p$-trifluoromethyl and ester-substituted $N$-(2iodophenyl)acetamides led to decreased yields of the desired compounds (Table 2, entries 4 and 5). Various halogens (F, Cl, $\mathrm{Br})$ in para-position were well-tolerated on substrates $\mathbf{1}$ (Table 2, entries 6-8). Then, halogen-substituents ( $\mathrm{F}, \mathrm{Cl})$ in meta position gave moderate yields (Table 2, entries 9 and 10). While a $m$-ester group on reactant $\mathbf{1 k}$ resulted in a decreased yield (Table 2, entry 11). Other types of acetonitriles substituted with electron-withdrawing groups $\left(-\mathrm{CO}_{2} \mathrm{Me},-\mathrm{SO}_{2} \mathrm{Me}\right.$, $-\mathrm{SO}_{2} \mathrm{Ph}$, and $-\mathrm{PO}(\mathrm{OEt})_{2}$ ) were also investigated. Unfortunately, 
$-\mathrm{CO}_{2} \mathrm{Me}$ and $-\mathrm{PO}(\mathrm{OEt})_{2}$ failed to afford the desired product under the same conditions, while $-\mathrm{SO}_{2} \mathrm{Me}$ and $-\mathrm{SO}_{2} \mathrm{Ph}$ produced moderate isolated yields of the target products (Table 2, entries 12 and 13). Furthermore, the catalytic system tolerated a variety of substituted $o$-iodobenzaldehydes in the reaction. For $o$-iodobenzaldehyde substrates, electron-donating methoxy groups decreased the yield (Table 2, entry 14). However, a methyl group at the para-position of iodine in reactant $\mathbf{3 c}$ resulted in a good yield (Table 2, entry 15). Halogen-substituted ( $\mathrm{F}, \mathrm{Cl}$ ) substrates 3 also provided the desired products with moderate yields (Table 2, entries 16 and 17).

\section{Conclusion}

In conclusion, we have developed a simple and efficient $\mathrm{Cu}$-catalyzed methodology for the synthesis of indolo[1,2a]quinazoline derivatives. This approach produced nitrogencontaining tetracyclic compounds in moderate to good yields from simple starting materials. This method will provide an opportunity for the construction of diverse and useful nitrogen-containing tetracyclic compounds that incorporate the bioactive indole motif in organic chemistry and medicinal chemistry.

\section{Experimental}

\section{General procedure for the synthesis of indolo[1,2-a]quinazolines $\mathbf{4 a - 4 q}$}

A dry sealed tube was charged with a magnetic stirrer, substituted $\mathrm{N}$-(2-iodophenyl)acetamide (100 $\mathrm{mg}$ for each example, $0.38 \mathrm{mmol})$, malononitrile or 2-sulfonylacetonitriles ( $0.46 \mathrm{mmol}, 1.2$ equiv), $\mathrm{CuI}$ ( $0.038 \mathrm{mmol}, 0.1$ equiv), L-proline ( 0.076 mmol, 0.2 equiv), and $\mathrm{K}_{2} \mathrm{CO}_{3}(0.76 \mathrm{mmol}, 2$ equiv) in $0.77 \mathrm{~mL}$ of DMSO. The tube was evacuated and backfilled with argon and the process was repeated three times. The mixture was stirred at $80{ }^{\circ} \mathrm{C}$ for $12 \mathrm{~h}$ under an argon atmosphere. After the starting material was consumed completely, 2-iodobenzaldehyde ( $0.4 \mathrm{mmol}, 1.05$ equiv) with $0.77 \mathrm{~mL}$ of DMSO was charged successively to the tube via syringe, and then the resulting mixture was stirred at $80{ }^{\circ} \mathrm{C}$ for another $12 \mathrm{~h}$ under an argon atmosphere. After the reaction was complete, the reaction mixture was cooled to room temperature and the reaction mixture was partitioned between ethyl acetate or dichloromethane and water. The organic layer was separated and the aqueous layer was extracted with ethyl acetate or dichloromethane for three times. The combined organic solution was washed with water, brine, dried over anhydrous $\mathrm{Na}_{2} \mathrm{SO}_{4}$, and concentrated under reduced pressure to give the crude product. Purification by chromatography on silica gel using petroleum ether/ethyl acetate or dichloromethane/ethyl acetate as eluent provided the desired product.

\section{Supporting Information}

\section{Supporting Information File 1}

General information, experimental details, characterization data and copies of ${ }^{1} \mathrm{H}$ and ${ }^{13} \mathrm{C}$ NMR spectra.

[http://www.beilstein-journals.org/bjoc/content/ supplementary/1860-5397-10-254-S1.pdf]

\section{Acknowledgements}

We gratefully acknowledge financial support from the National Natural Science Foundation of China (Grants 21021063, 91229204, and 81025017), sponsored by Program of Shanghai Subject Chief Scientist (Grant12 XD1407100).

\section{References}

1. Aygun, A.; Pindur, U. Curr. Med. Chem. 2003, 10, 1113-1127. doi:10.2174/0929867033457511

2. Rodrigues de Sá Alves, F.; Barreiro, E. J.; Manssour Fraga, C. A. Mini-Rev. Med. Chem. 2009, 9, 782-793. doi:10.2174/138955709788452649

3. Ishikura, M.; Yamada, K.; Abe, T. Nat. Prod. Rep. 2010, 27 , 1630-1680. doi:10.1039/c005345g

4. Welsch, M. E.; Snyder, S. A.; Stockwell, B. R. Curr. Opin. Chem. Biol. 2010, 14, 347-361. doi:10.1016/j.cbpa.2010.02.018

5. Pons, V.; Beaumont, S.; Dau, M. E. T. H.; lorga, B. I.; Dodd, R. H. ACS Med. Chem. Lett. 2011, 2, 565-570. doi:10.1021/ml200024y

6. Vangrevelinghe, E.; Zimmermann, K.; Schoepfer, J.; Portmann, R.; Fabbro, D.; Furet, P. J. Med. Chem. 2003, 46, 2656-2662. doi:10.1021/jm030827e

7. Xu, H.; Fan, L.-I. Eur. J. Med. Chem. 2011, 46, 364-369. doi:10.1016/j.ejmech.2010.10.022

8. Okuro, K.; Furuune, M.; Miura, M.; Nomura, M. J. Org. Chem. 1993, 58, 7606-7607. doi:10.1021/jo00078a053

9. Ma, D.; Cai, Q. Acc. Chem. Res. 2008, 41, 1450-1460. doi:10.1021/ar8000298

10. Monnier, F.; Taillefer, M. Angew. Chem., Int. Ed. 2008, 47, 3096-3099. doi:10.1002/anie.200703209

11. Wang, B.; Lu, B.; Jiang, Y.; Zhang, Y.; Ma, D. Org. Lett. 2008, 10, 2761-2763. doi:10.1021/ol800900a

12. Wang, F.; Liu, H.; Fu, H.; Jiang, Y.; Zhao, Y. Org. Lett. 2009, 11, 2469-2472. doi:10.1021/ol900847t

13. Xie, X.; Cai, G.; Ma, D. Org. Lett. 2005, 7, 4693-4695. doi:10.1021/ol0518838

14. Xie, X.; Chen, Y.; Ma, D. J. Am. Chem. Soc. 2006, 128, 16050-16051. doi:10.1021/ja066991j

15. Yip, S. F.; Cheung, H. Y.; Zhou, Z.; Kwong, F. Y. Org. Lett. 2007, 9 , 3469-3472. doi:10.1021/ol701473p

16. Adepu, R.; Sunke, R.; Meda, C. L. T.; Rambabu, D.; Krishna, G. R.; Reddy, C. M.; Deora, G. S.; Parsa, K. V. L.; Pal, M. Chem. Commun. 2013, 49, 190-192. doi:10.1039/c2cc37070k

17. Liu, T.; Wang, R.; Yang, H.; Fu, H. Chem. - Eur. J. 2011, 17, 6765-6771. doi:10.1002/chem.201100690

18. Lu, J.; Gong, X.; Yang, H.; Fu, H. Chem. Commun. 2010, 46, 4172-4174. doi:10.1039/c0cc00185f 
19. Sunke, R.; Adepu, R.; Kapavarapu, R.; Chintala, S.; Meda, C. L. T.; Parsa, K. V. L.; Pal, M. Chem. Commun. 2013, 49, 3570-3572. doi:10.1039/c3cc41337c

20. Jiang, M.; Li, J.; Wang, F.; Zhao, Y.; Zhao, F.; Dong, X.; Zhao, W. Org. Lett. 2012, 14, 1420-1423. doi:10.1021/ol3001624

21. Chen, Y.; Wang, Y.; Sun, Z.; Ma, D. Org. Lett. 2008, 10, 625-628. doi:10.1021/ol7029382

22. Yang, X.; Fu, H.; Qiao, R.; Jiang, Y.; Zhao, Y. Adv. Synth. Catal. 2010, 352, 1033-1038. doi:10.1002/adsc.200900887

23. Kobayashi, K.; Komatsu, T.; Yokoi, Y.; Konishi, H. Synthesis 2011, 764-768. doi:10.1055/s-0030-1258422

24. Evano, G.; Blanchard, N.; Toumi, M. Chem. Rev. 2008, 108, 3054-3131. doi:10.1021/cr8002505

25. Altman, R. A.; Koval, E. D.; Buchwald, S. L. J. Org. Chem. 2007, 72, 6190-6199. doi:10.1021/jo070807a

26. Davis, O. A.; Hughes, M.; Bull, J. A. J. Org. Chem. 2013, 78, 3470-3475. doi:10.1021/jo400120r

27. Antilla, J. C.; Klapars, A.; Buchwald, S. L. J. Am. Chem. Soc. 2002, 124, 11684-11688. doi:10.1021/ja027433h

28. Ziegler, D. T.; Choi, J.; Muñoz-Molina, J. M.; Bissember, A. C.; Peters, J. C.; Fu, G. C. J. Am. Chem. Soc. 2013, 135, 13107-13112. doi:10.1021/ja4060806

29. Alajarin, M.; Bonillo, B.; Ortin, M.-M.; Orenes, R.-A.; Vidal, A. Org. Biomol. Chem. 2011, 9, 6741-6749. doi:10.1039/c1ob05745f

30. Kiruthika, S. E.; Perumal, P. T. Org. Lett. 2014, 16, 484-487. doi:10.1021/ol403365t

31. Kotha, S.; Shah, V. R. Eur. J. Org. Chem. 2008, 1054-1064. doi:10.1002/ejoc.200700921

32. Shimada, T.; Nakamura, I.; Yamamoto, Y. J. Am. Chem. Soc. 2004, 126, 10546-10547. doi:10.1021/ja047542r

33. Zhou, P.-X.; Luo, J.-Y.; Zhao, L.-B.; Ye, Y.-Y.; Liang, Y.-M. Chem. Commun. 2013, 49, 3254-3256. doi:10.1039/c3cc40577j

\section{License and Terms}

This is an Open Access article under the terms of the Creative Commons Attribution License (http://creativecommons.org/licenses/by/2.0), which permits unrestricted use, distribution, and reproduction in any medium, provided the original work is properly cited.

The license is subject to the Beilstein Journal of Organic Chemistry terms and conditions:

(http://www.beilstein-journals.org/bjoc)

The definitive version of this article is the electronic one which can be found at: $\underline{\text { doi:10.3762/bjoc. } 10.254}$ 